\title{
PENGARUH PEMBERIAN EKSTRAK BUAH KELOR (Moringa oleifera) TERHADAP PENURUNAN KADAR KOLESTROL PADA DARAH HEWAN MENCIT (Mus musculus)
}

\section{Effect of Giving Moringa (Moringa oleifera) Fruit Extract on Lowering Blood Cholesterol Levels Ofmice (Mus musculus)}

\author{
*Eva Zulviana, Nurdin Rahman, dan Supriadi \\ Pendidikan Kimia/FKIP - Universitas Tadulako, Palu - Indonesia 94118 \\ Recieved 06 December 2016, Revised 05 January 2017, Accepted 08 February 2017
}

\begin{abstract}
This study aimed to identify bioactive compounds of moringa (moringa oleifera) extracts and determine the effective concentration on lowering blood cholesterol levels of mice. The animals used were 15 male mice induced by propylthiouracil and fat food diet. The mice were divided randomly into 5 groups with different treatment groups. The first, the second, and the third treatments were given Moringa extracts each with a concentration of 10\%, 20\% and 40\%. The fourth treatment group was given food fat diet and propiltiorasil as a positive control, and the fifth treatment was given standard food and distilled water as a negative control. Data were analyzed using a statistical analysis of variance (ANOVA) test followed by Duncan test. The results showed that moringa fruit extract contains alkaloids, saponins, flavonoids and tannins. Moringa fruit extract can lower blood cholesterol levels of mice with the most effective concentration of $10 \%$.
\end{abstract}

Keywords: moringa fruit, cholesterol, blood, bioactive.

\section{Pendahuluan}

Kolesterol merupakan salah satu komponen susu yang terdapat sebagai lapisan tipis lemak susu. Sebagian besar lemak di dalam tubuh dan makanan terdapat dalam bentuk trigliserida yang dapat berbentuk lemak jenuh dan lemak tak jenuh. Hiperkolesterolemia merupakan penyakit gangguan metabolisme kolesterol yang disebabkan oleh kadar kolesterol dalam darah melebihi batas normal (Murray, dkk., 2003).

Sebagian besar hiperlipidemia tidak memberikan gejala dan tanda klinis, namun terdapat gejala yang nyata disebut xantoma yaitu penumpukan jaringan lemak dibawah kulit yang sering dijumpai antara lain dilipatan kelopak mata. Bila kadar kolesterol tidak terkontrol, lama-kelamaan akan menumpuk, menjadi aterosklerosis dan penyakit jantung koroner (Nurwahyunani, 2006).

Pemberian filtrat buah kelor (moringa oliefera) adalah $2.76 \mathrm{mg} / \mathrm{dl}$ yang dibuktikan

\section{*Correspondence:}

Eva Zulviana

Program Studi Pendidikan Kimia, Fakultas Keguruan dan Ilmu Pendidikan, Universitas Tadulako

email: evazulviana88@yahoo.com

Published by Universitas Tadulako 2017 dengan hasil uji Paired T-test menunjukkan bahwa probabilitasnya $0.006<0.05$ (Kristinawati \& Nurlaela, 2013). Hasil penelitiannya menunjukkan buah kelor mengandung senyawa aktif yaitu alkaloid dan flavanoid. Kedua senyawa ini di duga efektif menurunkan rasa nyeri akibat rematik, menghambat pembentukan asam urat dan bersifat anti inflamasi serta analgetik. Selain itu, senyawa alkaloid dan flavanoid juga dapat menurunkan kadar kolesterol darah (Salam, 2011). Dengan adanya kandungan metabolit sekunder dari buah kelor, mendorong peneliti untuk melakukan penelitian mengenai efek ektrak buah kelor terhadap penurunan kadar kolesterol darah pada mencit.

Pemanfaatan tanaman kelor khususnya buah kelor muda sebagai obat tradisional belum maksimal digunakan oleh masyarakat. Senyawa aktif yang terkandung dalam buah kelor adalah alkaloid. Selain alkaloid buah kelor mengandung flavonoid, tanin, saponin. Keempat senyawa ini efektif menurunkan rasa nyeri akibat rematik, antimikroba, menjaga kesehatan reproduksi, menghambat pembentukan asam urat dan bersifat anti inflamasi serta analgetik (Mulyo, 2007). 
Tulisan ini dimaksudkan untuk menginvestigasi efek ekstrak buah kelor dalam menurunkan kadar kolesterol darah mencit dan menentukan konsentrasi paling efektif. Manfaat dari penelitian ini yaitu diharapkan dapat menjadi media visual mata kuliah farmasi mengenai gangguan metabolisme karbohidrat pada penderita hiperkolesterolemia dengan pemanfaatan buah kelor sebagai penurunan kadar kolesterol.

\section{Metode}

\section{Alat dan Bahan}

Alat-alat yang digunakan dalam penelitian adalah sebagai berikut: Nesco multicheck, spoit oral, gelas ukur $10 \mathrm{~mL}$, gelas kimia 150 $\mathrm{mL}$, Labu ukur $50 \mathrm{~mL}$, kandang hewan uji, timbangan hewan, batang pengaduk, blender, talenan, pisau/cutter, pompa vokum, penangas air, tabung reaksi, neraca digital, Erlenmeyer $100 \mathrm{~mL}$, sarung tangan, masker, gunting, pipet tetes, batang pengaduk, corong, lumpang dan alu, lap halus

Bahan-bahan yang digunakan dalam penelitian diantaranya: buah kelor (Moringa oleivera) di pasar inpres Palu, larutan propiltiorisil, hewan uji (mencit), aquades, tissue, kapas, etanol $\left(\mathrm{C}_{2} \mathrm{H}_{5} \mathrm{OH}\right)$ (Merck), pereaksi Mayer (Merck), $\mathrm{HCl}$ pekat (Merck), $\mathrm{FeCl}_{3}$ (Merck K GaA), alkohol 70\%, kertas saring, dan larutan $\mathrm{H}_{2} \mathrm{SO}_{4}$ (Merck K GaA).

\section{Cara Kerja}

Pembuatan ektrak buah kelor

Serbuk buah kelor ditimbang sebanyak 10 gram dan dimasukkan ke dalam gelas kimia yang berisi aquades $100 \mathrm{~mL}$. Dipanaskan selama 15 menit dengan suhu $90^{\circ} \mathrm{C}$, kemudian campuran disaring dalam keadaan panas menggunakan kain flanel dan jika volume kurang dari $100 \mathrm{~mL}$, maka ditambahkan air hangat melalui residu hasil saringan hingga volume mencapai $100 \mathrm{~mL}$. Ektrak buah kelor $20 \%$ dan $40 \%$ dibuat dengan cara yang sama menggunakan 20 gram dan 40 gram.

\section{Pembuatan Uji Kualitatif Ektrak Buah Kelor}

Uji pendahuluan yang dilakukan pada penelitian ini mengikuti prosedur yang telah dilakukan oleh peneliti sebelumnya (Rinaldi, 2011).

\section{Uji Alkaloid}

$1 \mathrm{~g}$ sampel ditimbang lalu ditambahkan 10 $\mathrm{mL}$ etanol $70 \%$ kemudian dipanaskan di atas penangas air selama 2 menit lalu ditambahkan 2 tetes Dragendorf. Jika hasil memberikan endapan kuning, orange sampai merah bata maka sampel mengandung alkaloid.

\section{Uji Saponin}

Diambil sedikit ekstrak dan dimasukkan dalam tabung reaksi. Ekstrak ditambah aquades dengan perbandingan ekstrak dan aquades 1 : 1, kemudian dikocok dan didiamkan. Jika terbentuk buih yang tidak menghilang selama 30 menit, maka ekstrak tanaman tersebut mengandung saponin.

\section{Uji Flavonoid}

Ekstrak dilarutkan dengan etanol 70\%, ditambah dengan 2 tetes $\mathrm{HCl}$ pekat, diamati warna yang terjadi. Larutan dihangatkan di atas pemanas air selama 15 menit, kemudian diamati perubahan warna yang terjadi. Terbentuknya warna merah kuat atau violet, menunjukkan adanya senyawa flavonoid.

\section{Uji Tanin}

Sebanyak $2 \mathrm{~mL}$ sampel buah kelor yang telah diekstraksi dengan pelarut etanol, dipanaskan kurang lebih 5 menit. Setelah dipanaskan ditambahkan beberapa tetes $\mathrm{FeCl}_{3} 1 \%$. Jika larutan terbentuk warna coklat kehijauan atau biru kehitaman maka positif mengandung tanin.

\section{Pembuatan Propiltiourasil 0,01\%}

Mempermudahkeadaanhiperkolesterolemia diberikan propiltiourasil pada mencit melalui air minumnya dengan konsentrasi PTU (Propiltiourasil) sebesar 0,01\% artinya dalam 1 liter air terlarut $10 \mathrm{~mL}$ PTU. Propiltiourasil (PTU) berfungsi meningkatkan kadar kolesterol dengan cara menghambat sintesis hormon tiroid.

\section{Pembuatan Makanan Diet lemak Tinggi}

Makanan diet lemak tinggi terdiri dari campuran kuning telur, minyak goreng dan jagung. Cara pembuatannya, kuning telur dicampurkan dengan jagung kemudian campurkan dengan minyak bantuan pemanasan. Setelah tercampur, dinginkan. Lalu masukkan kuning telur.

\section{Pemilihan dan penyiapan hewan uji}

Hewan uji yang digunakan adalah mencit (Mus musculus) jantan berbadan sehat, berumur 2-3 bulan dengan berat badan antara 20 gram sampai 30 gram. Tikus yang digunakan sebanyak 15 ekor dan dibagi dalam 5 kelompok. 


\section{Perlakuan terhadap hewan uji}

Sebelum perlakuan pada hewan uji, mencit dipuasakan terlebih dahulu selama 16 jam. Kemudian dilakukan pengukuran kadar kolestrol pada mencit. Kemudian hewan uji diinduksi dengan mengkonsumsi propiltiourasil dan makanan diet lemak selama 2 minggu. Lalu dilakukan pengukuran kadar kolestrol. Kemudian mencit dibagi menjadi 5 kelompok, dan dilakukan pengujian sebagai berikut :

P1 : Perlakuan 1 (Makanan standar (jagung) + makanan tinggi lemak + PTU + Aquades 1 $\mathrm{mL}+$ ekstrak buah kelor 10\%); P2 : Perlakuan 2 (Makanan standar (jagung) + makanan tinggi lemak + PTU + Aquades $1 \mathrm{~mL}+$ ekstrak buah kelor 20\%); P3 : Perlakuan 3 (Makanan standar (jagung) + makanan tinggi lemak + PTU + Aquades $1 \mathrm{~mL}$ + ekstrak buah kelor 40\%); P4 : Perlakuan 4 atau kontrol positif (makanan tinggi lemak + PTU + Aquades $1 \mathrm{~mL}) ; \mathrm{P} 5$ : Perlakuan 5 atau kontrol negatif (Makanan standar (jagung) + Aquades $1 \mathrm{~mL}$ )

Setelah diberikan pelakuan semua mencit diistirahatkan ke dalam kandangnya masingmasing dan diberikan makanan dan minuman. Kadar kolestrol darah diukur pada hari ke 0, 5 dan 10 yaitu pengukuran kolestrol darah akhir.

\section{Penentuan kadar kolesterol darah}

Sebelum digunakan, Nesco multicheck dihidupkan dan strip cholesterol dimasukkan ke dalam Nesco multicheck. Darah diambil melalui ujung ekor hewan uji (mencit) kemudian di teteskan pada Nesco multicheck. Dalam waktu 150 detik kadar kolesterol darah akan terukur secara otomatis dan hasilnya dapat dibaca pada monitor Nesco multicheck.

\section{Analisa Data}

Setelah hasil data kolesterol darah awal diperoleh yang meliputi, kolesterol darah setelah induksi, kolesterol darah setelah perlakuan, dan penurunan kolesterol dari kelima perlakuan tersebut selanjutnya dianalisis dan dievaluasi dengan menggunakan rancangan acak kelompok melalui uji statistik analisis sidik ragam (uji F) dengan taraf kepercayaan 95\%. Uji ini digunakan untuk mengetahui perbedaan yang signifikan dari semua perlakuan, dan jika terdapat perbedaan maka pengujian dilanjutkan dengan uji Duncan untuk mengetahui perlakuan mana yang mempunyai perbedaan yang nyata.

\section{Hasil dan Pembahasan}

\section{Uji Senyawa Fitokimia Ektrak Buah Kelor} (Moringa oleifera)

Hasil pengamatan pada uji pendahuluan terhadap adanya senyawa alkaloid, saponin, flavonoid dan tannin maka diperoleh data Tabel 1.

Tabel 1 Hasil Uji Fitokimia Ekstrak Buah

\begin{tabular}{|c|c|c|c|}
\hline \multicolumn{4}{|c|}{ Kelor (Moringa oleifera) } \\
\hline Uji & Reagen & Pengamatan & Hasil \\
\hline Alkaloid & Pereaksi Reagen Mayer. & $\begin{array}{l}\text { Endapan putih dan } \\
\text { menghasilkan warna } \\
\text { orange }\end{array}$ & Positif \\
\hline Saponin & Aquades $1: 1$ & Terbentuk Buih & Positif \\
\hline Flavonoid & HCL pekat & $\begin{array}{l}\text { Terbentuk warna merah } \\
\text { bata }\end{array}$ & Positif \\
\hline Tanin & $\mathrm{FeCL}_{3} 1 \%$ & $\begin{array}{l}\text { Terbentuk warna coklat } \\
\text { kehijauan }\end{array}$ & Positif \\
\hline
\end{tabular}

Penurunan kadar kolesterol darah pada mencit, dapat diketahui melalui perhitungan selisih antara kadar kolesterol darah setelah diinduksi dengan kadar kolesterol darah setelah pemberian perlakuan. Grafik yang menunjukkan penurunan kolesterol darah pada mencit terlihat pada Gambar 1

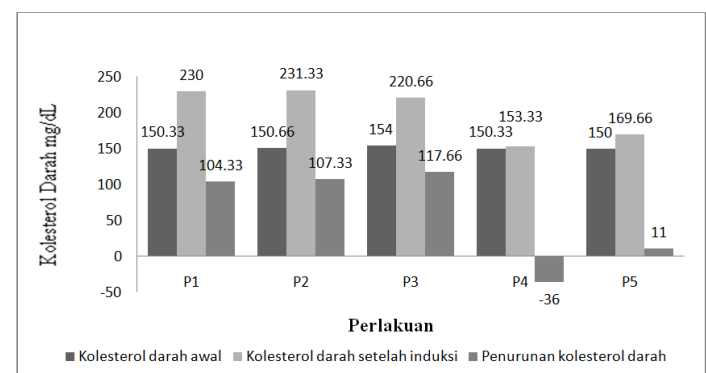

Gambar 1. Rerata Kadar Kolesterol Darah Awal, Setelah Induksi dan Penurunan Kolesterol Darah

Dimana : P1: Makanan standar + makanan diet lemak tinggi + PTU + Aquades $1 \mathrm{~mL}+$ ekstrak buah kelor 10\% ; P2: Makanan standar + makanan diet lemak tinggi + PTU + Aquades $1 \mathrm{~mL}+$ ekstrak buah kelor 20\% ; P3: Makanan standar + makanan diet lemak tinggi + PTU + Aquades $1 \mathrm{~mL}+$ ekstrak buah kelor 40\%) ; P4: Perlakuan 4 atau kontrol positif (makanan diet lemak tinggi + PTU + Aquades $1 \mathrm{~mL})$ dan P5 : Perlakuan 5 atau kontrol negatif (Makanan standar + Aquades $1 \mathrm{~mL}$ )

\section{Hasil Perhitungan Statistik Uji Anova}

Perbedaan yang signifikan antar kelima perlakuan dapat diketahui dengan melakukan uji statistik menggunakan analisis varians (Anova), terlihat pada Tabel 2. 
Tabel 2 Data SPSS hasil uji ANOVA untuk

\begin{tabular}{llrrrr}
\multicolumn{5}{c}{ penurunan kolesterol } \\
\hline & $\begin{array}{l}\text { Sum of } \\
\text { Squares }\end{array}$ & Df & $\begin{array}{c}\text { Mean } \\
\text { Square }\end{array}$ & F & P \\
\hline Between & 57433.733 & 4 & 14358.433 & 7.468 & .005 \\
Groups & & & & & \\
Within Groups & 19226.000 & 10 & 1922.600 & & \\
Total & 76659.733 & 14 & & & \\
\hline
\end{tabular}

Setelah uji Anova tersebut, kemudian dilanjutkan dengan uji Duncan. Uji ini untuk mengetahui pada perlakuan mana yang memiliki perbedaan yang bermakna dalam menentukan konsentrasi yang paling efektif dalam menurunkan kolesterol darah. Hasil uji Duncan terlihat pada Tabel 3.

Tabel 3 Hasil uji Duncan untuk penurunan kolesterol

\begin{tabular}{lrrr}
\hline & \multicolumn{3}{c}{ Subset for alpha $=.05$} \\
\cline { 3 - 4 } Perlakuan & N & 2 & \multicolumn{1}{c}{1} \\
\hline P4 & 3 & -36.0000 & \\
P5 & 3 & 11.0000 & \\
P1 & 3 & & 104.3333 \\
P2 & 3 & & 107.3333 \\
P3 & 3 & & 117.6667 \\
Sig. & & .219 & .730
\end{tabular}

Penelitian ini menggunakan hewan uji mencit, umur 2-3 bulan dengan berat ratarata 20-30 gram. Pemilihan hewan uji karena ketersediannya yang cukup tinggi dan cukup peka untuk mewakili manusia dalam penentuan kadar kolesterol darah. Mencit memiliki sistem metabolisme dan sistem pencernaan yang relatif sama dengan manusia (Salam, 2011). Yang digunakan pada penelitian ini yaitu mencit jantan karena mencit jantan dapat memberikan hasil penelitian yang lebih stabil dan juga mempunyai kecepatan metabolisme obat yang lebih cepat serta kondisi biologis tubuh yang lebih stabil dibanding mencit betina. Selain itu mencit jantan tidak dipengaruhi oleh siklus hormonal (siklus reproduksi). Siklus hormonal hanya terjadi pada hewan betina sebagai akibat sekresi hormon estrogen dan progesterone pada proses ovulasi. Estrogen dan progesterone yang disekresikan ovarium untuk membantu proses pembuangan sisa hasil metabolism tubuh dan menghambat terbentuknya produk yang tidak mempunyai fungsi fisiologis (Mulyo, 2007).

Mencit terlebih dahulu dipuasakan selama 16 jam sebelum diberi perlakuan. Tujuan dari perlakuan ini adalah untuk meminimalkan faktor makanan yang dapat mempengaruhi kadar kolestrol darah pada saat pengukuran. Setelah itu mencit tersebut diukur kolestrol darahnya dengan menggunakan Nesco Multicheck. Selanjutnya mencit diinduksi dengan menggunakan propiltiourasil melalui air minumnya dengan konsentrasi $0,01 \%$ artinya dalam 1 liter air terlarut $100 \mathrm{mg}$ Propiltiourasil (PTU). PTU berfungsi meningkatkan kadar kolesterol dengan cara menghambat sintesis hormon tiroid, Dan makanan diet lemak tinggi terdiri dari campuran kuning telur dan makanan standar. Diet hiperkolesterolemia dapat meningkatkan kadar kolesterol total dan kadar LDL dalam darah.hal ini sesuai dengan penelitian yang dilakukan oleh (Gani, dkk., 2013). Peningkatan kadar kolestrol dapat disebabkan oleh 3 hal. Pertama, diet yang terlalu banyak mengandung kolestrol dan lemak sehingga tubuh tidak mampu mengendalikannya. Kedua, ekskrasi ke kolom melalui asam empedu terlalu sedikit. Ketiga, apabila produksi kolesterol dalam hati terlalu banyak (Baraas, 2003).

Pengukuran kadar kolesterol pada mencit yang telah diberi perlakuan dilakukan pada hari 0,5 dan 10. Hal ini dilakukan karena pada hari ke 0 penurunan kolestrol darah pada mencit belum terlalu turun sehingga dilakukan kembali pengukuran pada hari ke 5. Kemudian, karena hari ke 5 belum terlalu ada perbedaan penurunan yang signifikan sehingga dilakukan pemeriksaan pada hari ke 10 .

Hasil uji statistik One Way ANOVA pada tingkat kepercayaan 95\% menunjukkan bahwa terdapat perbedaan kadar kolesterol yang signifikan antar tiap kelompok perlakuan yang diberi diet lemak dengan pemberian ekstrak air buah kelor. Rata-rata kadar penurunan kolesterol tertinggi terdapat pada P3 (40\%) yaitu $117 \mathrm{mg} / \mathrm{dL}$ sedangkan yang terendah pada $\mathrm{P} 4$ yaitu $-36 \mathrm{mg} / \mathrm{dL}$. Hal ini menunjukkan bahwa pemberian ekstrak air buah kelor memberikan pengaruh terhadap penurunan kadar kolesterol pada hewan coba. Hal ini ditunjukkan pada perlakuan P1 dan P2 yang memiliki rata-rata penurunan kadar kolesterol yang lebih tinggi dari kontrol positif yang merupakan perlakuan tanpa pemberian ektrak air buah kelor dan dipaksa untuk naik kadar kolesterolnya. Menurut Anwar (2005), Konsentrasi kolesterol HDL yang tinggi dalam darah mencegah pembentukan aterosklerosis sehingga menurunkan jumlah kasus penyakit jantung koroner. Dalimartha (2012), 
menyatakan bahwa timbulnya ateroslerosis berawal dari tingginya kadar kolestrol kadar kolestrol (LDL) akibat kurangnya pembentukan reseptor LDL sebagai kelainan genetic seperti hiperkolesterolemia familial atau jenuhnya reseptor LDL sehubungan dengan konsumsi makanan yang terlalu banyak mengandung kolestrol tinggi.

Sedangkan pada perlakuan P5 (kontrol negative) penurunan kadar kolesterolnya lebih tinggi dibandingkan dengan penurunan kadar kolesterol P4 hal ini disebabkan karena pemberian makanan diet lemak pada kontrol positif sedangkan pada kontrol negative tidak diberikan makanan diet lemak tinggi, tujuan pada perlakuan ini sebagai pembanding antara perlakuan yang diberikan ektrak buah kelor, makanan diet lemak dan makanan standar.

Tabel 2 menunjukkan bahwa antara perlakuan mempunyai nilai signifikan 0,05 < $\alpha=0,050$ atau nilai $\mathrm{F}$ hitung $=7.468$. Hal ini menandakan bahwa terdapat suatu penurunan kadar kolestrol yang cukup bermakna dari kelima kelompok perlakuan. Setelah uji Anova tersebut, kemudian dilanjutkan dengan uji Duncan. Uji ini untuk mengetahui pada perlakuan mana yang memiliki perbedaan yang bermakna dalam menentukan konsentrasi yang paling efektif dalam menurunkan kolestrol darah. Hasil Uji Duncan pada kadar kolesterol total menunjukkan bahwa antara P1 (perlakuan dengan konsentrasi 10\%) dan kelompok P4 (perlakuan tanpa menggunakan ekstrak) terdapat perbedaan nyata hal ini disebabkan karena adanya pemberian ektrak buah kelor pada P1 sedangkan pada P4 tanpa menggunakan ekstrak buah kelor. Berdasarkan presentase kadar kolesterol sebelum dan setelah pemberian filtrat buah kelor menunjukkan bahwa filtrat buah kelor mampu menurunkan kadar kolesterol Kadar kolesterol darah kontrol positif dan negative tidak mengalami perubahan yang bermakna karena tidak diberi intervensi seperti kelompok perlakuan P1, P2 dan P3 sehingga kontrol positif dan negative dapat digunakan sebagai pembanding kadar kolesterol darah mencit sebelum dan setelah pemberian filtrat buah kelor.

Adanya perbedaan kadar kolesterol sebelum dan setelah pemberian filtrat buah kelor disebabkan oleh zat aktif dalam buah kelor seperti alkaloid, flavanoid, tanin dan saponin.
Flavonoid berperan sebagai antioksidan yang dapat menekan pelepasan radikal $\mathrm{O}_{2}$ yang reaktif sehingga menekan terjadinya kerusakan endotel dengan menghambat inisiasi atau propagasi dari reaksi rantai oksidasi dan sebagai anti inflamasi yang dapat menghambat reaksi inflamasi, sehingga mencegah makin banyaknya makrofag (Zarrabal, dkk., 2005). Flavanoid juga berperan menurunkan penyerapan kolesterol dan asam empedu serta meningkatkan aktivitas reseptor kolesterol LDL (Susilo \& Rachmad, 2008).

Mekanisme utama saponin dan tanin dalam menurunkan kolesterol total adalah dengan mekanisme mencegah reabsorpsi dan meningkatkan ekskresi kolesterol (Khyade \& Vaikos, 2009). Saponin dapat berikatan dengan kolesterol pada lumen intestinal sehingga dapat mencegah reabsorpsi kolesterol. Selain itu, saponin juga dapat berikatan dengan asam empedu, sehingga dapat menurunkan sirkulasi enterohepatik asam empedu dan meningkatkan ekskresi kolesterol (Alkanji, dkk., 2009). Saponin merupakan senyawa tanaman yang memiliki surfaktan yang dapat berikatan dengan kolesterol dan empedu sehingga menurunkan absorpsi kolesterol dalam tubuh (Ratnawati \& Widowati, 2011). Saponin dengan kolesterol ternyata juga memiliki reseptor yang sama, sehingga dapat terjadi kompetisi reseptor kolesterol pada sel. Selain itu, saponin juga dapat mempengaruhi biosintesis kolesterol di hati (Alkanji, dkk., 2009).

Berdasarkan penelitian sebelumnya, tanin memiliki potensi meningkatkan ekskresi asam empedu, sehingga dapat menurunkan kadar kolesterol. Tanin memiliki aktivitas antihiperlipidemia dengan mekanisme menghambatbiosintesiskolesterol, menurunkan absorpsi kolesterol diet, menurunkan kadar kolesterol serum dan meningkatkan ekskresi asam empedu (Choudhary, 2013).

\section{Kesimpulan}

Ekstrak buah kelor dapat menurunkan kadar kolesterol darah pada mencit. Rata-rata penurunan kolesterol darah pada perlakuan I dengan ekstrak buah kelor 10\% sebesar 104,33 $\mathrm{mg} / \mathrm{dL}$, perlakuan II dengan ekstrak buah kelor $20 \%$ sebesar $107,33 \mathrm{mg} / \mathrm{dL}$, perlakuan III dengan ekstrak buah kelor 40\% sebesar 117,66 $\mathrm{mg} / \mathrm{dL}$, perlakuan IV dengan pakan diet lemak 
tanpa ekstra buah kelor sebesar $-36 \mathrm{mg} / \mathrm{dL}$ dan perlakuan $\mathrm{V}$ tanpa perlakuan sebesar $11 \mathrm{mg} /$ dL. Hasil penelitian menunjukkan bahwa ekstrak buah kelor dapat menurunkan kadar gula kolesterol mencit dengan konsetrasi paling efektif $10 \%$ dengan $\alpha=0,05$.

\section{Ucapan Terima Kasih}

Penulis mengucapkan terima kasih kepada Idha Kesuma Utami selaku laboran Laboratorium Agroteknologi Fakultas Pertanian Universitas Tadulako yang telah menuntun selama penelitian.

\section{Referensi}

Alkanji, M. A., Ayorinde, B. T., \& Yakubu, M. T. (2009). Anti-lipidaemic Potentials of Aqueous extract of tapinanthus globiferus leaves in rats. chemistry and medicinal value, 25, 1-9.

Anwar, D. M. (2005). Konsepsi kesehatan dalam islam. from http//psikologi.tripod. com/konsepsikesehatan.html.

Baraas, F. (2003). Kardiologi molekuler: radikal bebas, disfungsi endotel aterosklerosis, antioksidan, latihan fisik, dan rehabilitas jantung. Jakarta: Yayasan Kardi Iqratama.

Choudhary, G. P. (2013). Hypocholesterolemic effect of ethanolic extract of fruits of terminalia chebula in high fat diet fed foster rats. International Journal of Advances In Pharmacy, Biology and Chemistry, 2(1), 1315.

Dalimartha, S. (2003). Resep tumbuhan obat untuk asam urat. Jakarta: Penebar swadaya.

Gani. N., Momuat. L. I., \& Pitoi M. M. (2013). Profil lipida plasma tikus wistar yang hiperkolesterolemia pada pemberian gedi merah (abelmoschus manihot L.). Jurnal Matematika dan IImu Pengetahuan Alam Universitas Samratulangi, 2(1), 44-49.

Khyade, M. S., \& Vaikos, N. P. (2009). Pharmacognostical and preliminary phytochemical studies on the leaf of alstonia macrophylla. Journal of Herbal Medicine and Toxicology, 3(2), 127-132.

Kristinawati, E., \& Nurlaela. (2013). Pengaruh pemberian filtrat buah kelor (moringa oliefera) tehadap kadar asam urat pada hewan coba tikus putih (rattus norvegicus) strain wistar. Media Bina Ilmiah, 7(6), 2732.

Mulyo, J. H. S. (2007). Pengaruh pemberian ekstrak daun kelor (moringa oliefera) terhadap kadar asam urat darah mencit (mus musculus) Hiperlipidemia. Uneversitas Islam Negeri Malang, Malang.

Murray, R. K., Granner, D. K., \& Rodwell, V. W. (2003). Biokimia harper. Jakarta : Buku Kedokteran

Nurwahyunani. (2006). Efek perasan daun sambung nyawa terhadap kadar kolestrol LDL dan kolestrol HDL darah tikus diabetik akibat induksi streptozotocin. Universitas Semarang, Semarang.

Ratnawati, H., \& Widowati, W. (2011). Anticholesterol activity of velvet bean (mucuna pruriens 1.) towards hypercholesterolemic rats. Sains Malaysiana, 40(4), 317-321.

Rinaldi, B. (2011). Efek air perasan kulit buah rambutan (nephelium lappacium) terhadap penurunan kadar kolestrol total. Universitas Tadulako, Palu.

Salam, A. A. (2011). Uji efektifitas daun lere (ipomea pes-caprae (L) roth Br.) sebagai alternative untuk menurunkan kadar glukosa darah kelinci (ocyctologus) cuniculuus). Universitas Tadulako, Palu.

Susilo, K. D., \& Rachmad. (2008). Sosiologi Lingkungan. Jakarta: Rajawali Pers.

Zarrabal, O. C., Waliszewski, S. M., Dermitz, D. M. B., Flores, Z. O., Jones, P. M. H., Hipolito, C. N., \& Infazon, R. M. (2005). The consumption of hibiscus sabdariffa dried calyx ethanolic extract reduced lipid profile in rats. Plants Foods for Human Nutrition, 60(4), 153-159. 